\title{
PENGARUH KONSENTRASI TEPUNG MAIZENA DAN KONSENTRASI ASAM SITRAT TERHADAP SIFAT FISIK, KIMIA DAN ORGANOLEPTIK SELAI MAWAR
}

\section{Effect of Corn Starch and Citric Acid Concentration Level on Physico-Chemical and Organoleptic Properties of Rose Jam}

\author{
Putu Anggia Ayu Asasia*, Sudarminto Setyo Yuwono \\ Jurusan Teknologi Hasil Pertanian, FTP Universitas Brawijaya, Malang \\ JI. Veteran, Malang 65145 \\ *Penulis Korespondensi, Email : anggiasasia@yahoo.com
}

\begin{abstract}
ABSTRAK
Luasnya penggunaan selai pada produk makanan, menyebabkan permintaan produk selai terus meningkat. Eksplorasi bahan baku selai harus dilakukan untuk memenuhi permintaan konsumen. Penggunaan bunga mawar sebagai bahan baku selai dirasa tepat karena kandungan bunga mawar yang bermanfaat serta warna bunga mawar yang menarik. Masalah pada selai dengan bahan baku bunga mawar, yaitu selai tidak bisa mengental sehingga perlu penambahan tepung maizena sebagai agen pengental. Masalah lainnya, warna merah pada bunga mawar hilang seiring dengan proses pengolahan sehingga perlu penambahan asam sitrat agar pigmen antosianin pada mawar dapat stabil. Penelitian ini bertujuan untuk mengetahui penambahan konsentrasi asam sitrat dan tepung maizena yang optimal agar menghasilkan selai mawar yang berkualitas baik. Metode yang digunakan dalam penelitian ini adalah Rancangan Acak Kelompok (RAK) dengan 2 faktor. Faktor I yaitu penambahan maizena (5\%, 6\%, 7\%). Faktor II yaitu penambahan asam sitrat $(0.30 \% ; 0.50 \% ; 0.70 \%)$. Kombinasi yang diperoleh sebanyak 9 dengan 3 kali ulangan sehingga diperoleh 27 satuan percobaan. Hasil penelitian dianalisis dengan Analysis of Variance (ANOVA) dan dilakukan uji lanjut dengan uji BNT atau uji DMRT dengan selang kepercayaan 95\% dan uji non parametrik kruskal-wallis. Hasil perlakuan terbaik selai mawar diperoleh berdasarkan metode metode Zeleny. Perlakuan terbaik selai mawar dengan penambahan asam sitrat sebanyak $0.70 \%$ dan tepung maizena sebesar $5 \%$.
\end{abstract}

Kata Kunci : Asam Sitrat, Mawar, Selai, Tepung Maizena

\section{ABSTRACT}

The widespread use of jam products, causing the demand for jam continuous to increase. Exploration of raw materials of jam should be done to meet consumer demand. The use of roses as a raw material considered appropriate because of useful content of roses and the attractive color. One of the problems in the roses as the raw material is rose jam can not be thickened thus it needs addition of corn starch as thickening agent. Another problem is losing red color of roses during the process thus it needs addition of citric acid to stabilize the anthocyanin pigment. This research aims to determine the addition of corn starch and citric acid concentration to produce good quality of rose jam. The method that being used was Randomized Block Design with 2 factors. Factor I is the addition of corn starch (5\%, 6\%, 7\%). Factor II is the addition of citric acid (0.30\%; 0.50\%; 0.70\%). The combination obtained by 9 and with 3 replication, so the total of combination is 27 of units of experiements. The result were analyzed by Analysis of Variance (ANOVA) and tested with BNT test or DMRT test with 95\% interval confidence and Kruskall-wallis as non parametric test. The best treatment of rose jam was obtained based on Zeleny method. 
This study indicated that rose jam with the addition of $0.70 \%$ citric acid and addition of $5 \%$ corn starch was the best treatment based on physicochemical parameter.

Keyword: Citric Acid, Cornstarch, Jam, Rose

\section{PENDAHULUAN}

Penggunaan selai pada berbagai produk makanan, menyebabkan permintaan akan selai terus meningkat. Eksplorasi akan bahan baku baru pembuatan selai harus terus dilakukan untuk memenuhi permintaan konsumen. Bahan baku selai yang sedang berkembang saat ini adalah bunga. Ketersediaan bunga yang melimpah serta mudahnya bunga ditemui membuat bunga memiliki potensi sebagai bahan baku selai. Salah satu bunga yang memiliki potensi sebagai bahan baku selai adalah bunga mawar. Produksi mawar kota Batu sendiri mengalami peningkatan setiap tahunnya, dimana pada tahun 2012 produksi mawar sebanyak 8.8 juta potong dan mengalami kenaikan pada tahun 2014 yaitu mencapai 29.6 juta potong (BPS, 2015). Fungsi utama bunga mawar sebagai bahan baku selai yaitu sebagai pewarna serta menyumbang antioksidan pada produk selai. Bunga mawar yang digunakan pada penelitian ini yaitu bunga mawar jenis Rosa damascena Mill. yang biasa digunakan oleh masyarakat sebagai bunga mawar tabur. Pemilihan bunga mawar tabur ini dikarenakan bunga mawar tersebut memiliki nilai jual yang lebih rendah dibandingkan dengan mawar lainnya.

Selai membutuhkan zat penstabil, yang berfungsi sebagai pengental atau perekat. Permasalahan dari bunga mawar yaitu tidak mengandung pektin sebagai salah satu syarat komponen utama selai. Solusi yang diberikan yaitu penggantian pektin dengan tepung maizena atau tepung jagung karena maizena mempunyai kemampuan untuk membentuk gel. Tepung maizena memiliki harga yang lebih ekonomis serta mudah didapat dibandingkan dengan pektin.

Masalah lainnya, pada pembuatan selai mawar pemberian bahan pembuatan selai mawar seperti gula, air, tepung maizena dapat meningkatkan $\mathrm{pH}$ selai yang menyebabkan perubahan warna pada selai, dimana warna bunga mawar berasal dari pigmen antosianin. Pigmen antosianin bunga mawar mempunyai sifat sinergis dengan asam sitrat, yang terbukti berfungsi sebagai antioksidan (Lopes, et al., 2010; Garz'on et al., 2009; Yue \& Xu, 2008; Saati, 2008). Pigmen antosianin akan optimal jika berada pada $\mathrm{pH}$ rendah. Selain itu, asam sitrat mampu membentuk cita rasa dari selai bunga mawar. Tujuan penelitian ini adalah untuk mengetahui formulasi konsentrasi maizena dan asam sitrat untuk menghasilkan selai mawar yang memiliki karakteristik fisikokimia yang baik serta dapat diterima oleh konsumen berdasarkan uji organoleptik.

\section{BAHAN DAN METODE}

\section{Bahan}

Bahan yang digunakan dalam penelitian ini adalah mawar tabur, Asam Sitrat Komersial "toko Makmur", tepung maizena "Maizenaku", gula "Gulaku", air mineral "Prima". Bahan yang digunakan untuk analisis yaitu akuades, methanol PA, $\mathrm{HCl} 37 \%$, buffer $\mathrm{pH} \mathrm{1}$, buffer $\mathrm{pH} 4.5$.

\footnotetext{
Alat

Alat yang digunakan dalam proses pembuatan selai mawar yaitu timbangan, thermometer $110^{\circ} \mathrm{C}$, blender, panci, kompor, gelas arloji, gelas ukur $100 \mathrm{ml}$, spatula besi, sendok. Alat yang dibutuhkan untuk analisis yaitu oven, spektrofotometer, vortex, color reader, $\mathrm{pH}$ meter, sentrifuge, timbangan analitik, penggaris dan juga beberapa glassware seperti pipet tetes, pipet ukur $10 \mathrm{ml} ; 1 \mathrm{ml}$, erlenmeyer, beaker glass, tabung reaksi, spatula, bola hisap, labu ukur, gelas ukur dan gelas plastik kecil.
} 


\section{Rancangan Penelitian}

Pada penelitian kali ini menggunakan metode penelitian Rancangan Acak Kelompok (RAK) faktorial. Variabel penelitian melibatkan 2 faktor perlakuan yakni perbandingan penambahan tepung maizena dan penambahan asam sitrat. Terdapat 3 level variasi pada faktor perlakuan perbandingan tepung maizena $(3 \%, 5 \%, 7 \%)$ yang dilakukan cross link dengan 3 level variasi pada faktor perlakuan penambahan asam sitrat $(0.50 \% ; 0.60 \%$; $0.70 \%)$. Setiap unit perlakuan akan dilakukan pengulangan sebanyak 3 kali sehingga diperoleh 27 satuan percobaan. Data dianalisis dengan menggunakan ANOVA dilanjutkan dengan uji lanjut BNT atau DMRT dengan selang kepercayaan 95\%. Sedangkan data tidak normal dianalisis dengan nonparametrik dengan kurskal-wallis menggunakan minitab 17. Data organoleptik dianalisis menggunakan Minitab Friedman. Pemilihan perlakuan terbaik menggunakan metode Zeleny.

\section{Pembuatan Selai Mawar}

Bunga mawar diambil kelopak bunga mawar saja dan ditimbang sebanyak 20 gram kemudian dicuci dengan air mengalir. Kelopak Bunga mawar yang telah ditimbang diblender dengan menggunakan air mineral sebanyak $70 \mathrm{ml}$ sehingga bunga mawar menjadi hancur dan berbentuk slurry selama 30 detik. Slurry bunga mawar kemudian ditambahkan dengan gula sebanyak, asam sitrat sebanyak $0.30 \%(\mathrm{~b} / \mathrm{v}) ; 0.50 \%(\mathrm{~b} / \mathrm{v}) ; 0.70 \%(\mathrm{~b} / \mathrm{v})$ dan tepung maizena sebanyak $5 \%(\mathrm{~b} / \mathrm{v}) ; 6 \%(\mathrm{~b} / \mathrm{v}) ; 7 \%(\mathrm{~b} / \mathrm{v})$. Untuk tepung maizena dilarutkan dahulu dengan menggunakan air mineral sebanyak $30 \mathrm{ml}$. Bahan yang sudah dicampurkan kemudian dimasak diatas kompor hingga suhu suhu $90 \pm 5^{\circ} \mathrm{C}$ selama 2.5 menit. Selai mawar yang telah jadi kemudian dimasukkan ke dalam gelas kaca dengan hot filling dan didinginkan.

\section{Analisis}

Pengamatan yang dilakukan meliputi analisis bahan baku, fisik, kimia dan organoleptik. Analisis tersebut meliputi Kadar Air (AOAC, 1990), pH (Apriyanto dkk, 1989), Antosianin (Gao and Mazza, 1996), Aktivitas Antioksidan (Tranggono dan Sutardi, 1990), Sineresis (Imeson, 1992), Tekstur, Daya Oles (Yuwono dan Susanto, 1998), Warna (Yuwono dan Susanto, 1998). Pengujian organoleptik menggunakan uji kesukaan skala hedonik. Penentuan perlakuan terbaik dengan metode Zeleny.

\section{HASIL DAN PEMBAHASAN}

\section{Karakteristik Bahan Baku}

Hasil analisis karakteristik bunga mawar tabur Rosa damascena Mill yang digunakan dalam penelitian ditunjukkan pada Tabel 1.

Tabel 1. Karakteristik Bunga Mawar Sebagai Bahan Baku Selai Mawar

\begin{tabular}{lc}
\hline Kadar & Hasil Analisis \\
\hline Air (\%) & $89.45 \pm 0.46$ \\
Aktivitas Antioksidan (\%) & $92.17 \pm 1.27$ \\
Antosianin (mg/L) & $347.83 \pm 35.30$ \\
\hline Keterangan: & \\
- Setiap data merupakan rerata 3 kali ulangan \\
- Angka setelah tanda \pm menunjukkan nilai standar deviasi
\end{tabular}

\section{Karakteristik Kimia Selai Mawar}

Rerata hasil analisis selai mawar akibat perlakuan penambahan konsentrasi maizena dan asam sitrat kimia ditunjukkan pada Tabel 2 dan 3. 
Tabel 2. Pengaruh Konsentrasi Tepung Maizena Terhadap Karakteristik Kimia

\begin{tabular}{ccccc}
\hline $\begin{array}{c}\text { Konsentrasi } \\
\text { Maizena (\%) }\end{array}$ & $\begin{array}{c}\text { Kadar Air } \\
(\%)\end{array}$ & pH & Antosianin (\%) & $\begin{array}{c}\text { Aktivitas } \\
\text { Antioksidan* } \\
(\%)\end{array}$ \\
\hline 5 & $\begin{array}{c}39.40 \pm 1.79 \\
\mathrm{a}\end{array}$ & $3.01 \pm 0.25$ & $36.09 \pm 10.44 \mathrm{c}$ & $94.00 \pm 1.29$ \\
6 & $\begin{array}{c}41.00 \pm 1.47 \\
\mathrm{~b}\end{array}$ & $3.03 \pm 0.27$ & $33.83 \pm 10.23 \mathrm{~b}$ & $90.83 \pm 2.40$ \\
7 & $\begin{array}{c}44.48 \pm 0.66 \\
\mathrm{c}\end{array}$ & $3.02 \pm 0.26$ & $31.39 \pm 9.55 \mathrm{a}$ & $88.48 \pm 3.90$ \\
\hline
\end{tabular}

Keterangan: - Setiap data merupakan rerata 3 kali ulangan

- Angka setelah tanda \pm menunjukkan nilai standar deviasi

- Rerata dengan huruf yang berbeda menunjukkan pengaruh berbeda nyata

*) berbeda nyata dengan menggunakan uji kruskal-wallis

Tabel 3. Pengaruh Konsentrasi Asam Sitrat Terhadap Karakteristik Kimia

\begin{tabular}{|c|c|c|c|c|}
\hline $\begin{array}{c}\text { Konsentrasi Asam } \\
\text { Sitrat (\%) }\end{array}$ & $\begin{array}{l}\text { Kadar Air } \\
(\%)\end{array}$ & $\mathrm{pH}^{*}$ & Antosianin (\%) & $\begin{array}{c}\text { Aktivitas } \\
\text { Antioksidan* } \\
(\%)\end{array}$ \\
\hline 0.3 & $\begin{array}{c}42.9 \pm 1.63 \\
a\end{array}$ & $3.28 \pm 0.02$ & $23.45 \pm 2.17 \mathrm{a}$ & $88.58 \pm 4.19$ \\
\hline 0.5 & $\begin{array}{c}41.38 \pm 3.25 \\
a\end{array}$ & $3.02 \pm 0.01$ & $33.83 \pm 2.02 b$ & $91.18 \pm 2.65$ \\
\hline 0.7 & $\begin{array}{c}40.59 \pm 2.94 \\
b\end{array}$ & $2.76 \pm 0.01$ & $43.58 \pm 2.99 c$ & $93.54 \pm 1.60$ \\
\hline Keterangan:- & $\begin{array}{l}\text { Iap data meru } \\
\text { igka setelah ta } \\
\text { rata dengan h } \\
\text { nyata } \\
\text { erbeda nvata c }\end{array}$ & $\begin{array}{l}\text { an rerata } 31 \\
\text { a } \pm \text { menunju } \\
\text { If yang berb }\end{array}$ & $\begin{array}{l}\text { ulangan } \\
\text { n nilai standar de } \\
\text { menunjukkan pe }\end{array}$ & asi \\
\hline
\end{tabular}

\section{Kadar Air}

Hasil analisis ragam menunjukkan penambahan tepung maizena dan asam sitrat berpengaruh nyata terhadap kadar air selai mawar. Semakin tinggi konsentrasi maizena yang ditambahkan maka kadar air produk selai mawar akan semakin meningkat. Pada proses pembuatan selai mawar. terdapat proses pemasakan yang menggunakan panas sehingga pati jagung mengalami gelatinisasi dimana molekul granula dari pati menyerap air dari bahan terutama molekul amilopektin dari pati jagung. Pati memiliki kemampuan menyerap air karena memiliki kandungan gugus hidroksil. Molekul pati mengandung gugus hidroksil yang sangat besar sehingga kemampuan menyerap airnya juga sangat besar. Semakin besar kadar pati jagung yang digunakan. maka semakin kuat pula ikatan polimer yang telah terbentuk untuk memerangkap air. Granula pati akan menyerap air sehingga air yang terserap dalam bahan akan semakin banyak. Semakin tinggi konsentrasi asam sitrat yang ditambahkan maka kadar air produk selai mawar akan semakin menurun. Asam sitrat menurunkan kemampuan pati dalam menyerap air. Asam dapat menyebabkan ikatan hidrogen dalam pati melemah sehingga air tidak 
mudah terikat dengan granula pati. Air yang tidak diikat pati maka selama proses pemasakan selai. air akan mudah menguap sehingga kadar air produk selai mawar akan menurun. Asam sitrat dapat bereaksi dengan pati dan menyebabkan hidrolisis (Shi, et al., 2007). Hidrolisis pati dengan asam sitrat telah terbukti terjadi selama melt process (Carvalho, et al., 2005). dan selama Gelatinisasi (Hirashima, et al., 2004). Semakin rendah pH semakin banyak pemutusan rantai pati yang terjadi (Shi, et al., 2007).

\section{pH}

Hasil uji kurskal-wallis bahwa penambahan konsentrasi asam sitrat memberikan pengaruh terhadap nilai $\mathrm{pH}$ selai mawar. Semakin tinggi konsentrasi asam sitrat yang ditambahkan maka nilai $\mathrm{pH}$ produk selai mawar akan semakin menurun. Asam sitrat bersifat asam dan memiliki $\mathrm{pH}$ yang rendah sehingga penambahan asam sitrat ke dalam produk selai mawar menyebabkan selai mawar yang dihasilkan memiliki sifat asam. Semakin tinggi penambahan asam sitrat maka $\mathrm{pH}$ akan menurun (semakin asam) karena asam sitrat merupakan senyawa asidulan yang bersifat asam yang mampu menurunkan $\mathrm{pH}$. selain itu. asam sitrat yang ditambahkan akan terurai dalam larutan dan melepaskan ion $\mathrm{H}_{+}$. Adanya ion-ion $\mathrm{H}_{+}$dalam larutan akan menyebabkan keasaman larutan meningkat dan menyebabkan nilai $\mathrm{pH}$ semakin menurun.

\section{Antosianin}

Hasil analisis ragam menunjukkan bahwa konsentrasi tepung maizena dan asam sitrat memberi pengaruh nyata terhadap kadar antosianin selai mawar. Semakin tinggi konsentrasi maizena yang ditambahkan maka kadar antosianin produk selai mawar akan semakin menurun. Proporsi bahan baku mawar yang digunakan pada pembuatan produk selai mawar sama untuk semua perlakuan. Semakin besar penambahan tepung maizena memperkecil konsentrasi dari bunga mawar sebagai penyumbang pigmen antosianin. Pigmen antosianin penyumbang warna merah yang berada pada produk selai mawar berasal dari mawar yang digunakan sebagai bahan baku dalam pembuatan selai mawar. Semakin tinggi konsentrasi asam sitrat yang ditambahkan maka kadar antosianin produk selai mawar akan semakin meningkat. Hal ini disebabkan karena asam sitrat mempu memberikan suasana asam pada produk selai mawar. Suasana asam ini mampu menstabilkan pigmen antosianin yang terkandung pada selai mawar. Semakin tinggi penambahan asam sitrat maka $\mathrm{pH}$ akan menurun (semakin asam) karena asam sitrat merupakan senyawa asidulan yang bersifat asam yang mampu menurunkan $\mathrm{pH}$. Bentuk kation (ion flavium) yang berwarna merah. stabil pada $\mathrm{pH}$ rendah dan kestabilannya berubah menjadi tidak berwarna jika $\mathrm{pH}$ meningkat menuju netral.

\section{Aktivitas Antioksidan}

Hasil uji kurskal-wallis bahwa penambahan konsentrasi tepung maizena dan asam sitrat memberikan pengaruh terhadap aktivitas antioksidan. Semakin tinggi konsentrasi maizena yang ditambahkan maka aktivitas antioksidan produk selai mawar akan semakin menurun. Proporsi bahan baku mawar yang digunakan pada pembuatan produk selai mawar sama untuk semua perlakuan. Semakin besar penambahan tepung maizena memperkecil konsentrasi dari bunga mawar sebagai sumber antioksidan. Senyawa yang mengandung gugus fenol seperti antosianin bunga mawar merah ini dapat mencegah oksidasi serum sehingga bermanfaat pada kesehatan manusia (Saati, 2012). Semakin tinggi konsentrasi asam sitrat yang ditambahkan maka aktivitas antioksidan produk selai mawar akan semakin meningkat. Penambahan konsentrasi asam sitrat menyebabkan $\mathrm{pH}$ pada produk selai mawar semakin asam. Pigmen antosianin sebagai sumber antioksidan pada produk selai mawar stabil pada $\mathrm{pH}$ asam. Pada $\mathrm{pH}$ sangat asam (1-2). bentuk dominan antosianin adalah ion flavinium yang mana kondisi ini paling stabil dan paling berwarna. Selain itu. pada kondisi asam tinggi senyawa antioksidan lebih stabil. Stabilitas dan aktivitas senyawa antioksidan ekstrak dengan $\mathrm{pH}$ rendah lebih besar daripada ekstrak dengan $\mathrm{pH}$ tinggi. 
Hal ini berhubungan dengan terjadinya regenerasi senyawa antioksidan primer. Semakin rendah $\mathrm{pH}$ ekstrak berarti dalam ekstrak tersebut semakin banyak $\mathrm{H}+$ bebas. $\mathrm{H}+$ ini dapat meregenerasi senyawa antioksidan dengan cara berikatan dengan radikal fenoksi membentuk senyawa antioksidan kembali.

\section{Karakteristik Fisik Selai Mawar}

Rerata hasil analisis selai mawar akibat perlakuan penambahan konsentrasi maizena dan asam sitrat kimia ditunjukkan pada Tabel 4 dan 5 .

Tabel 4. Pengaruh Konsentrasi Tepung Maizena Terhadap Karakteristik Fisik

\begin{tabular}{cccc}
\hline $\begin{array}{c}\text { Konsentrasi } \\
\text { Maizena } \\
(\%)\end{array}$ & $\begin{array}{c}\text { Sineresis* } \\
(\%)\end{array}$ & $\begin{array}{c}\text { Tekstur* } \\
(\mathbf{N})\end{array}$ & $\begin{array}{c}\text { Daya Oles* } \\
(\mathbf{c m})\end{array}$ \\
\hline 5 & $14.03 \pm 1.99$ & $0.78 \pm 0.06$ & $5.92 \pm 0.42$ \\
6 & $10.13 \pm 1.86$ & $1.28 \pm 0.05$ & $4.79 \pm 0.54$ \\
7 & $8.33 \pm 0.97$ & $1.79 \pm 0.02$ & $3.49 \pm 0.37$ \\
\hline
\end{tabular}

Keterangan:

- Setiap data merupakan rerata 3 kali ulangan

- Angka setelah tanda \pm menunjukkan nilai standar deviasi

*) berbeda nyata dengan menggunakan uji kruskal-wallis

Tabel 5. Pengaruh Konsentrasi Asam Sitrat Terhadap Karakteristik Fisik

\begin{tabular}{cccc}
\hline $\begin{array}{c}\text { Konsentrasi } \\
\text { Asam Sitrat } \\
(\%)\end{array}$ & $\begin{array}{c}\text { Sineresis } \\
(\%)\end{array}$ & $\begin{array}{c}\text { Tekstur } \\
\mathbf{( N )}\end{array}$ & $\begin{array}{c}\text { Daya Oles } \\
(\mathbf{c m})\end{array}$ \\
\hline 0.3 & $9.35 \pm 2.49$ & $1.29 \pm 0.53$ & $4.24 \pm 1.22$ \\
0.5 & $10.61 \pm 3.87$ & $1.28 \pm 0.46$ & $4.92 \pm 1.11$ \\
0.7 & $12.52 \pm 3.43$ & $1.27 \pm 0.53$ & $5.03 \pm 1.33$ \\
\hline
\end{tabular}

Keterangan:

- Setiap data merupakan rerata 3 kali ulangan

- Angka setelah tanda \pm menunjukkan nilai standar deviasi

*) berbeda nyata dengan menggunakan uji kruskal-wallis

\section{Sineresis}

Hasil uji kurskal-wallis bahwa penambahan konsentrasi tepung maizena dan asam sitrat memberi pengaruh terhadap tingkat sineresis selai mawar. Semakin tinggi konsentrasi maizena yang ditambahkan maka tingkat sineresis produk selai mawar akan semakin menurun. Pati tepung maizena dapat berikatan dengan air sehingga mencegah air dapat keluar dari gel pati. Penambahan konsentrasi pengental akan mengurangi terjadinya sineresis secara signifikan (Goncalves, et al., 2005). Semakin tinggi konsentrasi pati yang ditambahkan maka ikatan hidrogen antara molekul air dan molekul amilopektin akan semakin banyak sehingga tingkat sineresis juga semakin menurun. Semakin tinggi konsentrasi asam sitrat yang ditambahkan maka tingkat sineresis produk selai mawar akan semakin meningkat. Asam dapat menyebabkan ikatan hidrogen dalam pati melemah sehingga air tidak mudah terikat dengan granula pati. Asam sitrat dapat bereaksi dengan pati dan menyebabkan hidrolisis (Shi, et al., 2007). Hidrolisis pati dengan asam sitrat telah terbukti terjadi selama melt process (Carvalho, et al., 2005) dan selama Gelatinisasi (Hirashima, et al., 2004). Semakin rendah pH semakin banyak pemutusan rantai pati yang terjadi (Shi, et al., 2007). 


\section{Tekstur}

Hasil uji kurskal-wallis bahwa penambahan konsentrasi tepung maizena memberi pengaruh terhadap nilai Tekstur selai mawar. Semakin tinggi konsentrasi maizena yang ditambahkan maka nilai tekstur produk selai mawar akan semakin meningkat. Maizena mampu memberikan tekstur yang kokoh pada tekstur selai mawar yang menyebabkan semakin tingginya nilai tekstur pada produk selai mawar. Peningkatan nilai tekstur akibat meningkatnya konsentrasi tepung maizena yang ditambahkan diduga berkaitan dengan adanya amilosa dan amilopektin. Kadar amilosa akan meningkat dengan meningkatnya konsentrasi pati. Pada saat pembuatan selai mawar terdapat proses pemanasan yang dapat melemahkan ikatan hidrogen pada amilosa sehingga terjadi gelatinisasi yang berlanjut dengan difusi amilosa dan amilopektin. Pada saat proses pendinginan selai. pati yang telah mengalami gelatinisasi akan saling berikatan dan menghasilkan tekstur yang kompak sehingga menyebabkan nilai tekstur yang tinggi. Amilosa memiliki kemampuan membentuk gel yang kokoh. Pembentukan gel merupakan hasil penggabungan polimer-polimer pati setelah terjadinya proses pemanasan atau retrogradasi. Jumlah pati yang ada memberikan struktur yang kokoh.

\section{Daya Oles}

Hasil uji kurskal-wallis bahwa penambahan konsentrasi tepung maizena memberi pengaruh daya oles selai mawar. Semakin tinggi konsentrasi maizena yang ditambahkan maka daya oles produk selai mawar akan semakin menurun. Tekstur selai yang didapat dengan penambahan tepung maizena memiliki tekstur gel yang padat yang menyebabkan sulit ketika dioleskan. Tepung maizena terdiri dari amilosa dan amilopektin. Semakin tinggi penambahan tepung maizena yang ditambahkan maka kadar amilosa dan amilopektin akan bertambah. Proses pemasakan selai mawar dengan menggunakan panas dapat melemahkan ikatan hidrogen pada amilosa sehingga terjadi gelatinisasi yang berlanjut dengan difusi amilosa dan amilopektin. Pada saat proses pendinginan selai. pati yang telah mengalami gelatinisasi akan saling berikatan dan menghasilkan tekstur yang kompak sehingga menyebabkan selai mawar susah dioleskan yang menyebabkan menurunnya daya oles pada selai mawar. Pembentukan gel merupakan hasil penggabungan polimer-polimer pati setelah terjadinya proses pemanasan atau retrogradasi. Jumlah pati yang ada memberikan struktur yang kuat sehingga lebih tahan terhadap perlakuan mekanis.

\section{Warna}

Rerata hasil analisis ragam menunjukkan bahwa konsentrasi tepung maizena dan asam sitrat memberi pengaruh nyata terhadap warna ditunjukkan pada Tabel 6. Semakin tinggi konsentrasi maizena yang ditambahkan maka nilai kecerahan ( $L$ ) dan kekuningan (*b) produk selai mawar akan semakin meningkat. Proporsi bunga mawar yang digunakan pada semua perlakuan memiliki jumlah yang sama. Konsentrasi bunga mawar pada pembuatan selai mawar akan semakin turun seiring dengan meningkatnya konsentrasi maizena yang ditambahkan sehingga menyebabkan warna merah akan semakin pudar yang menyebabkan meningkatnya nilai kecerahan (L) kekuningan ( $\left.{ }^{*} b\right)$. Semakin banyak penambahan tepung maizena pada pembuatan selai mawar maka semakin banyak kristal pati transparan sehingga menghasilkan tingkat kecerahan yang tinggi. Penambahan maizena berfungsi untuk menurunkan penyusutan akibat pemasakan. memberi warna yang terang. meningkatkan elastisitas produk. membentuk tekstur yang padat. dan menarik air dari adonan. Semakin tinggi konsentrasi asam sitrat yang ditambahkan maka nilai kecerahan (L) produk selai mawar akan semakin menurun. Penambahan asam sitrat ini akan menguatkan kemerahan dari produk selai mawar sehingga warna merah cenderung pekat yang menyebabkan kecerahan dari produk selai mawar akan semakin turun. Penyumbang warna kemerahan ( $\left.{ }^{*} \mathrm{a}\right)$ berasal dari pigmen bunga mawar yaitu antosianin yang mana pigmen ini stabil pada $\mathrm{pH}$ rendah. Warna antosianin akan merah pada rentang $\mathrm{pH} 1-2 \mathrm{dan}$ 
cerise pada pH 3 [Saati, 2012]. Penambahan asam sitrat mampu menurunkan pH bahan. Sehingga. semakin tinggi asam sitrat yang ditambahkan maka nilai kemerahan ( $\left.{ }^{*} a\right)$ akan semakin tinggi. Asam bukanlah satu-satunya hal yang berpengaruh pada kemerahan. Interaksi dalam taraf nyata antar kedua faktor menunjukkan bahwa tepung maziena juga memiliki peran dalam perubahan nilai kemerahan $\left({ }^{*} a\right)$. Penambahan maizena sebagai agen pengental dalam mengurangi proporsi dari pigmen antosianin pada selai yang ditandai semakin pudarnya warna merah pada selai sehingga menyebabkan nilai kemerahan $\left({ }^{*} a\right)$ semakin turun. Selain itu. pati maizena merupakan pati jagung yang ketika proses gelatinisasi memiliki sifat translucent (tembus cahaya). Suspensi pati alami dalam air berwarna buram (opaque). namun proses gelatinisasi pada granula pati dapat meningkatkan transparansi larutan tersebut. Sifat ini dapat menutupi intensitas warna kemerahan ( ${ }^{*}$ a) selai mawar yang dibentuk oleh asam sitrat.

Tabel 6. Rerata Nilai Rerata Kecerahan (L). Kemerahan (a*). Kekuningan ( $b^{*}$ ) Selai Mawar Akibat Perbedaan Konsentrasi Asam Sitrat dan Tepung Maizena

\begin{tabular}{ccccc}
\hline $\begin{array}{c}\text { Konsentrasi } \\
\text { Asam Sitrat } \\
(\%)\end{array}$ & $\begin{array}{c}\text { Konsentrasi } \\
\text { Maizena } \\
(\%)\end{array}$ & $\begin{array}{c}\text { Kecerahan } \\
(\mathbf{L})\end{array}$ & $\begin{array}{c}\text { Kemerahan } \\
\left({ }^{*} \mathbf{a}\right)\end{array}$ & $\begin{array}{c}\text { Kekuningan } \\
\left({ }^{\star} \mathbf{b}\right)\end{array}$ \\
\hline 0.3 & 5 & $33.52 \pm 0.33$ & $24.33 \pm 0.30 \mathrm{ef}$ & $4.49 \pm 0.37$ \\
& 6 & $34.50 \pm 0.34$ & $23.02 \pm 0.90 \mathrm{~d}$ & $5.93 \pm 0.56$ \\
& 7 & $35.24 \pm 1.38$ & $19.93 \pm 0.47 \mathrm{a}$ & $5.99 \pm 0.13$ \\
\hline 0.5 & 5 & $32.21 \pm 1.34$ & $26.68 \pm 1.03 \mathrm{~h}$ & $4.86 \pm 0.42$ \\
& 6 & $32.78 \pm 1.60$ & $23.68 \pm 0.25 \mathrm{de}$ & $5.23 \pm 0.32$ \\
& 7 & $33.28 \pm 1.62$ & $21.00 \pm 0.52 \mathrm{ab}$ & $5.97 \pm 0.18$ \\
\hline 0.7 & 5 & $31.09 \pm 0.87$ & $28.95 \pm 0.85 \mathrm{i}$ & $4.52 \pm 0.13$ \\
& 6 & $31.89 \pm 0.69$ & $24.82 \pm 0.83 \mathrm{~g}$ & $5.19 \pm 0.43$ \\
& 7 & $32.87 \pm 1.22$ & $21.22 \pm 0.80 \mathrm{bc}$ & $5.76 \pm 0.44$ \\
\hline
\end{tabular}

Keterangan:

- Setiap data merupakan rerata 3 kali ulangan

- Angka setelah tanda \pm menunjukkan nilai standar deviasi

- Rerata yang didampingi notasi huruf yang tidak sama menyatakan berbeda nyata pada uji lanjut DMRT $(\alpha=0.05)$

\section{Karakteristik Organoleptik}

Rerata hasil analisis organoleptik selai mawar akibat perlakuan penambahan konsentrasi maizena dan asam sitrat ditunjukkan pada Tabel 7.

\section{Warna}

Hasil analisis statistik Friedman. perlakuan perlakuan penambahan asam sitrat dan penambahan maizena berpengaruh nyata. Terlihat jika produk selai mawar dengan tingkat kesukaan warna tertinggi memiliki nilai kemerahan ( ${ }^{*}$ a) yang lebih tinggi dibandingkan dengan produk selai mawar dengan dengan tingkat kesukaan warna terendah. Mawar sebagai bahan baku utama selai mawar memiliki pigmen antosianin. Pigmen antosianin lebih stabil pada suasana $\mathrm{pH}$ asam yaitu pada kisaran $\mathrm{pH}$ 1-5 (Shi, et al., 2007). Sedangkan. penambahan tepung maizena dapat mengurangi konsentrasi antosianin pada produk selai mawar. Penambahan maizena mempengaruhi proporsi dari bunga mawar yang sehingga menyebabkan pudarnya warna kemerahan yang dihasilkan dari pigmen antosianin. Kecenderungan panelis lebih memilih produk selai mawar dengan konsentrasi asam sitrat yang tinggi dengan konsentrasi maizena yang rendah yang menyebabkan warna produk selai mawar menjadi merah pekat dan tidak pudar sehingga produk selai mawar yang dihasilkan menjadi lebih menarik. 
Tabel 7. Rerata nilai rerata kesukaan akibat perbedaan konsentrasi tepung maizena dan asam sitrat

\begin{tabular}{cccccc}
\hline \multirow{2}{*}{$\begin{array}{c}\text { Konsentrasi } \\
\text { Asam Sitrat (\%) }\end{array}$} & $\begin{array}{c}\text { Konsentrasi } \\
\text { Maizena (\%) }\end{array}$ & \multicolumn{4}{c}{ Rerata Nilai Kesukaan } \\
\cline { 3 - 6 } & 5 & 3.85 & 3.33 & 3.50 & 3.40 \\
& 5.3 & 3.45 & 3.33 & 3.58 & 3.43 \\
& 6 & 3.15 & 3.35 & 3.55 & 3.35 \\
\hline 0.5 & 5 & 4.05 & 3.48 & 3.88 & 3.60 \\
& 5 & 4.05 & 3.45 & 3.78 & 3.68 \\
& 6 & 3.95 & 3.40 & 3.68 & 3.78 \\
\hline 0.7 & 7 & 4.13 & 3.48 & 3.53 & 3.38 \\
& 5 & 4.15 & 3.40 & 3.48 & 3.28 \\
& 6 & 3.95 & 3.38 & 3.53 & 3.70 \\
\hline
\end{tabular}

Keterangan:

${ }^{*}$ ) Hasil analisis statistik Friedman menunjukkan bahwa perlakuan perlakuan penambahan asam sitrat dan penambahan maizena berpengaruh nyata ( $p$-value $<0.05$ ) terhadap tingkat kesukaan panelis

\section{Aroma}

Berdasarkan hasil analisis statistik Friedman. tingkat kesukaan panelis terhadap aroma selai mawar tidak berbeda nyata. Wangi bunga mawar disebabkan karena adanya kandungan minyak atsiri di dalamnya. Minyak atsiri ini mengandung zat sitrat. sitronelol. geraniol. linalool. nerol. eugenol. feniletil alkhol. farnesol. dan non alil-dehida (Saati, 2006). Minyak atsiri pada mawar merah sekitar 0.006-1.00\% (citronellol. eugenol. asam galat dan linalool. Proporsi bunga mawar sebagai sumber aroma dari selai mawar memiliki proporsi yang sama menyebabkan aroma selai mawar menjadi sama. Panelis menjadi sulit untuk membedakan aroma dari selai mawar dengan perlakuan penambahan asam sitrat dan tepung maizena. Selain itu. panelis yang digunakan pada penelitian ini yaitu panelis tidak terlatih.

\section{Rasa}

Berdasarkan hasil analisis statistik Friedman. tingkat kesukaan panelis terhadap aroma selai mawar tidak berbeda nyata. Pembentuk rasa pada pembuatan selai mawar ini adalah asam sitrat. Asam sitrat merupakan suatu asidulan yaitu senyawa kimia yang bersifat asam yang ditambahkan pada proses pengolahan makanan dengan berbagai tujuan. Asidulan dapat bertindak sebagai penegas rasa dan warna atau menyelubungi after taste yang tidak disukai. Perbedaan rasa selai mawar tidak bisa dibedakan oleh panelis karena konsentrasi asam sitrat yang tidak terlalu jauh menyebabkan panelis sulit untuk membedakan rasa dari selai mawar . Selain itu. panelis yang digunakan pada penelitian ini yaitu panelis tidak terlatih.

\section{Tekstur}

Hasil analisis statistik Friedman menunjukkan perlakuan penambahan asam sitrat dan penambahan maizena berpengaruh nyata terhadap tingkat kesukaan panelis pada warna selai mawar. Terlihat jika produk selai mawar dengan tingkat kesukaan tekstur tertinggi memiliki nilai tekstur (tensile strength) yang lebih tinggi dibandingkan dengan produk selai mawar dengan 
dengan tingkat kesukaan tekstur terendah. Kecenderungan panelis lebih memilih lebih memilih produk selai mawar dengan konsentrasi asam sitrat yang rendah dengan konsentrasi maizena yang tengah yang menyebabkan tekstur produk selai mawar menjadi tidak terlalu padat dan tidak terlalu cair. Hal ini karena. pati pada tepung maizena yang pada saat proses pemasakan selai mawar mengalami proses gelatinisasi. Pada saat proses pendinginan selai pati yang telah mengalami gelatinisasi akan saling berikatan dan menghasilkan tekstur yang kompak dan cenderung padat. Sehingga semakin banyak tepung maizena yang ditambahkan maka kandungan pati akan semakin besar yang menyebabkan tekstur selai mawar menjadi padat. Sedangkan asam sitrat mampu menghidrolisis ikatan pati sehingga ikatan antar pati menjadi melemah menyebabkan tekstur selai menjadi kurang kompak.

\section{SIMPULAN}

Hasil penelitian menunjukkan perlakuan penambahan konsentrasi maizena berpengaruh nyata terhadap kadar antosianin. aktivitas antioksidan. sineresis. kadar air. tekstur (tensile strength), daya oles, kecerahan (L), kemerahan ( $\left.{ }^{*} a\right)$, kekuningan ( $\left.{ }^{*} b\right)$, parameter organoleptik (warna dan tekstur). Sedangkan perlakuan penambahan konsentrasi asam sitrat berpengaruh nyata terhadap derajat keasaman $(\mathrm{pH})$, kadar antosianin, aktivitas antioksidan, sineresis, kadar air, kecerahan (L), kemerahan ( $\left.{ }^{*} a\right)$, parameter organoleptik (warna dan tekstur). Terjadi interaksi antara perlakuan perbedaan konsentrasi penambahan maizena dan asam sitrat pada kemerahan ( $\left.{ }^{*} a\right)$. Perlakuan terbaik diperoleh pada selai mawar penambahan asam sitrat sebanyak $0.70 \%$ dan penambahan tepung maizena sebesar $5 \%$ berdasarkan parameter fisik. kimia. serta organoleptik. Karakteristik selai mawar perlakuan terbaik yaitu kadar air $37.94 \%$; derajat keasaman $(\mathrm{pH})$ 2.76; kadar antosianin $46.75 \mathrm{mg} / \mathrm{L}$; aktivitas antioksidan $95.16 \%$; sineresis 16.31\%; tekstur (tensile strength) $0.73 \mathrm{~N}$; daya oles $6.33 \mathrm{~cm}$; kecerahan (L) 31.09; kemerahan ( $\left.{ }^{*} a\right) 28.95$; kekuningan ( $\left.{ }^{*} b\right) 4.52$.

\section{DAFTAR PUSTAKA}

AOAC. 1990. Official Methods of Analysis. 15th edition. Edited by Helrich

Apriyanto A, Dedi F, Puspitasari N.L.S dan Slamet B. 1989. Analisis Pangan. PAU Pangan dan Gizi IPB. Bogor

Badan Pusat Statistik. 2015. Statistik Daerah Kota Batu 2015. Badan Pusat Statistik Kota Batu. Batu

Carvalho A.J.F, Zambon M.D, da Silva Curvelo A.A and Gandini A. 2005. Thermoplastic starch modification during melt processing: Hydrolysis catalyzed by carboxylic acids. Carbohydrate Polymers 62. 387-390

Gao L. and Mazza G. 1996. Extraction of Anthocyanin Pigments from Purple Sunflower Hulls. J. Food Science. 61: 600-603

Garz'on G.A, Riedi K.M and Schwartz S.J. 2009. Determination of Anthocyanins. Total Phenolic Content. and Antioxidant Activity in Andes Berry (Rubus glaucus Benth). J. Food Sci. 74(3): 227-232

Goncalves D, Perez C, Reolon G, Segura N, Lema P, Gambaro A, Varela P and Ares G. 2005. Effect of Thickener on The Texture of Stirred Yoghurt. Alim. Nutr. Araraquara. 16 (3): 207211

Hirashima M, Takahashi R, and Nishinari K. 2004. Effects of Citric Acid on the Viscoelasticity of Cornstarch Pastes. Journal of Agricultural and Food Chemistry 52. 2929-2933

Imeson A. 1992. Thickening and Gelling Agents for Food. New York: Blackie Academic \& Profesional 
Lopes D.J, Dettmann C.N and Schieber A. 2010. Characterization and Quantification of Polyphenols in Amazon Grape (Pourouma cecropiifolia Martius). J. Molecules. 15: 85438552

Saati, E.A. 2012. Potensi Pigmen Antosianin Bunga Mawar (Rosa sp.) Lokal Batu sebagai Zat Pewarna Alami dan Komponen Bioaktif Produk Pangan. Disertasi Doktor. Jurusan IImu Pertanian. Fakultas Pertanian. Universitas Brawijaya. Malang

Saati, E.A.. 2008. Function optimalization extract flower of kana as natural colourant and antioxidant by method isolating and characterizing the pigment. Proceeding International Reserch Seminar International Reserch Seminar and Exhibition .UMM Malang. 7-8 Nopember 2008

Saati, E.A dan Wachid M. 2006. Penggunaan Pigmen Antosianin Bunga Mawar Sortiran untuk Pewarna dan Penghambat Kerusakan Lemak pada Pangan Fermentasi. Proceeding Seminar Nasional PATPI 2. FTP UGM. Yogyakarta

Shi R, Zhang Z, Liu Q, Han Y, Zhang L, Chen D and Tian W. 2007. Characterization of Citric Acid/Glycerol Co-Plasticized Thermoplastic Starch Prepared by Melt Blending. Carbohydrate Polymers 69. 748-755

Tranggono dan Sutardi. 1990. Biokimia. Teknologi Pasca Panen dan Gizi. Yogyakarta: PAU Pangan dan Gizi Universitas Gajah Mada

Yue $X$ and $\mathrm{Xu} \mathrm{Z}$. 2008. Changes of Anthocyanins. Anthocyanidins. and Antioxidant Activity in Bilberry Extract During Dry Heating. J. Food Chem. 73 (6): 124-135

Yuwono S dan Susanto T. 1998. Pengujian Fisik Pangan. Jurusan Teknologi Hasil Pertanian. Universitas Brawijaya. Malang 